\title{
As máscaras de um duplo
}

\section{Vinicius Lucas de Souza ${ }^{1}$}

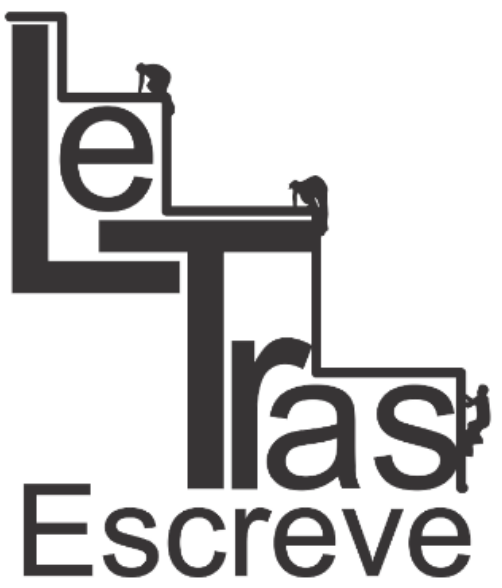

(ISSN 2238-8060)

\section{INTRODUÇÃO}

Resumo: $\mathrm{O}$ objetivo do presente texto é analisar o conto "Restos humanos", de Clive Barker, a fim de visualizar como se dá a construção do duplo nessa narrativa e como o tratamento desse tropo é inovado, ao adicionar características de outras criaturas ficcionais (vampiros, estátuas vivas, liches) à figura duplicante, extrapolando a abordagem tradicional do Doppelgänger.

Palavras-chave: "Restos humanos". Clive Barker. Duplo.

Abstract: The aim of the present paper is to analyze the short story "Human Remains", by Clive Barker, in order to visualise how the double is composed in such narrative and how the treatment of this motif is innovated, by adding characteristics of other fictional creatures (vampires, living statues, liches) to the doubling figure and, consequently, extrapolating the traditional approach to the Doppelgänger.

Keywords: "Human Remains". Clive Barker. Double.

Eu e outro, duplicado e duplicata, original e cópia, verdadeiro e falso: várias palavras que emergem do jogo de significação promovido pelo Doppelgänger, assim como são diversos os casos do duplo na Literatura, ao longo dos séculos, nos quais gêmeos, duplos e reflexos assombram, atormentam e distorcem a unidade identitária.

Na literatura do século XIX, por exemplo, pode-se pensar no conto "O homem da areia" ("Der Sandmann", 1816), de E. T. A. Hoffmann, em que o espectro maligno Coppelius-Coppola persegue e amaldiçoa a vida do estudante Nathanael; "William Wilson" (1839), de

\footnotetext{
${ }^{1}$ Graduado em Letras (Português/Inglês/Alemão) pela UNESP Faculdade de Ciências e Letras de Araraquara (2015), mestrando em Estudos Literários pela mesma universidade e bolsista de Mestrado do CNPq. Desenvolve pesquisa na área de Literaturas Estrangeiras Modernas, com ênfase em Literaturas de Língua Inglesa e Literatura Gótica, focando no motivo literário do duplo e suas transformações na Ficção. E-mail: viniciuslucassouza@gmail.com
}

https://periodicos.unifap.br/index.php/letras

Macapá, v. 7, n. 4, 20 semestre, 2017 
Edgar Allan Poe, com seu protagonista adentrando nas sendas do prazer, mas contantemente perseguido pelo seu outro, sua voz da consciência; O médico e o monstro (Strange Case of Dr. Jekyll and Mr. Hyde, 1886), romance de Robert Louis Stevenson, no qual o respeitável Dr. Henry Jekyll induz, por meio de uma droga, sua própria transformação no infame Mr. Edward Hyde; O retrato de Dorian Gray (The Picture of Dorian Gray, 1890; 1891), de Oscar Wilde, em que um retrato permite ao narcisista Dorian Gray manter sua bela juventude, ao mesmo tempo que a pintura retém as terríveis marcas das consequências de suas ações.

Nessa pequena amostra, é possível ter um vislumbre da imen-

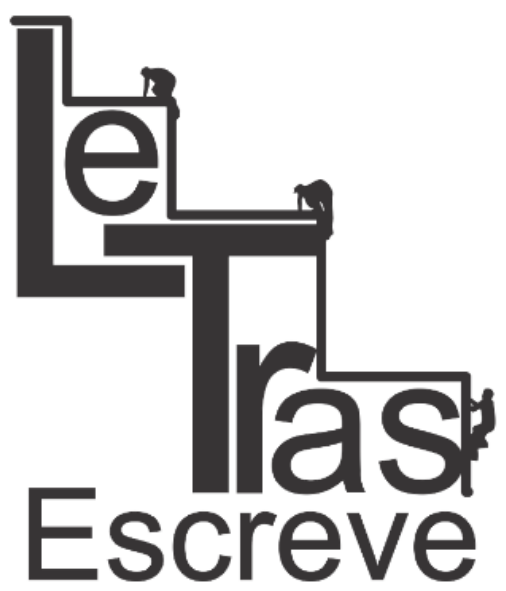

(ISSN 2238-8060) sa horda de duplos que povoa o cenário literário e que parte, nos séculos XX e XXI, para outras plataformas ficcionais, alastrando seu espectro de atuação no cinema, no graphic novel, na televisão.

Mergulhando no século XX, "Restos humanos" (“Human Remains", 1984) é um conto que aborda essa temática, coletado na série de contos Livros de sangue (Books of Blood, 1984-1985), de Clive Barker, escritor inglês que, além de ter ganhado notoriedade no campo da ficção gótica com a publicação da coleção mencionada, também é famoso por sua novela Hellraiser: renascido do inferno (The Hellbound Heart, 1986), centrada na caixa de Lemarchand e os horrores que dela surgem e caem sobre aqueles que a manuseiam. No conto em questão, um prostituto, após observar uma estátua de madeira deitada numa banheira, passa a ser perseguido por essa criatura, cuja aparência gradualmente transmuta-se na imagem do protagonista.

O objetivo do presente artigo é analisar essa narrativa de Clive Barker, a fim de visualizar como ela plasma a questão do duplo, principalmente no que concerne à criatura que replica a imagem do protagonista, uma vez que suas características expandem as idiossincra-

https://periodicos.unifap.br/index.php/letras

Macapá, v. 7, n. 4, 20 semestre, 2017 
sias tradicionais de um Doppelgänger - como visto em "William Wilson", de Poe, um ser cuja aparência física e detalhes da personalidade imitam as de seu "original" - , incorporando marcas de outras entidades ficcionais. Para tanto, embasarão nosso texto os ensaios que versam sobre o duplo de Otto Rank e Clément Rosset; "O 'estranho'" ("Das Umheimliche", 1919), de Sigmund Freud e os textos sobre o espelho e a água, respectivamente, de Umberto Eco e Gaston Bachelard.

Nas seguintes linhas, perseguiremos esse outro inquietante e seu modus operandi, não com o intuito de classificar sua natureza, mas notar como suas características e seu processo de replicação inovam a abordagem do tema do duplo.

\section{A VINDA DO OUTRO SEM NOME}

Em "Restos humanos", o leitor é introduzido ao protagonista Gavin, um prostituto que não limita sua clientela, atendendo desde ricas viúvas a maridos desesperados. A indiferença é o que, segundo o narrador, destaca esse "agente da noite":

(ISSN 2238-8060)

Algumas profissões costumam ser praticadas durante o dia; outras, à noite. Gavin era um profissional do segundo turno [...] A indiferença era sua marca registrada, talvez um dos pontos fortes de sua atração. O que simplificava a despedida quando a coisa terminava e o dinheiro era pago. (BARKER, 1990, p. 635)

Além de ser indiferente a seus clientes, outro aspecto ressaltado é sua obsessão pela própria beleza, próxima à perfeição:

[...] passava meia hora em frente ao espelho, inspe-

https://periodicos.unifap.br/index.php/letras

Macapá, v. 7, n. 4, 20 semestre, 2017 
cionando o próprio corpo. Sua autocrítica era severa. Jamais permitia uma variação maior de meio a um quilo no peso que considerava ideal, hidratava a pele quando estava seca, ou esfregava bastante com sabonete, quando estava oleosa, examinando cuidadosamente o rosto para detectar a ameaça de uma espinha.

[...] O rosto, oh, o rosto, diziam, abraçando-o com força, como se quisessem roubar um pedaço daquele encanto.

[...] Gavin [...] era a obra completa. Tudo que podia ser feito fora feito. Tratava-se, agora, de preservar a perfeição. (BARKER, 1990, p. 635-636)

Além da obsessão em manter sua beleza preservada, o controle sobre o tempo é outro aspecto obssessivo de sua personalidade, já que, mesmo em seus vinte anos, a personagem não evita a preocupação pelo envelhecimento, uma vez que ansia por se casar com uma viúva rica, sua aposentadoria:

\begin{abstract}
Uma onda de infelicidade subiu das profundezas de sua alma. Estava com vinte e quatro anos e cinco meses. Levava aquela vida, intermitentemente, desde os dezessete anos, prometendo a si mesmo que iria encontrar uma viúva rica (a aposentadoria do gigolô), ou uma profissão decente, antes dos vinte e cinco. Mas o tempo estava passando, e nem de longe ele sonhava realizar sua ambição. Fora-se o impulso inicial, e ele havia ganho mais uma linha sob os olhos. (BARKER, 1990, p. 640-641)
\end{abstract}

Nessa busca narcísea, o comportamento de Gavin assemelhase muito ao de Dorian Gray, a obsessão pela beleza juvenil e a corrida impossível contra o tempo, contra o envelhecer: "Se eu permanecesse sempre jovem e o retrato envelhecesse! Por isso - por isso - eu daria tudo! Sim, não há nada em todo o mundo que eu não daria! Daria a minha alma por isso!" (WILDE, 2012, p. 35, grifo nosso).

Durante sua rotina, o protagonista engaja num encontro com

https://periodicos.unifap.br/index.php/letras

Macapá, v. 7, n. 4, 20 semestre, 2017 
um cliente, Kenneth Reynolds, um restaurador de peças antigas. No apartamento deste, enquanto espera o cliente, Gavin observa as várias peças e fragmentos de ruínas romanas colecionadas pelo homem, mas uma delas chama sua atenção, uma lápide. Enquanto aguarda Reynolds resolver um barulho que os interrompeu, Gavin divaga sobre a pedra tumular e a imortalidade:

Flavinus, o porta-estandarte.

Havia algo de gratificante na ideia de ter o rosto perpetuado na pedra, numa forma um tanto rude, é verdade, e colocado ao lado dos próprios ossos, mesmo sabendo que, algum dia, um historiador iria separar a pedra dos ossos. O pai de Gavin quisera ser enterrado, e não cremado. Do contrário, dizia, como iriam lembrar dele? Quem iria chorar ao lado de uma urna, num nicho na parede? A ironia era que ninguém ia ao seu túmulo. Durante todos aqueles anos, desde a morte do pai, Gavin fora lá somente umas duas vezes. Uma pedra com uma data, um nome, uma frase feita. Nem se lembrava mais em que ano o pai havia morrido.

Mas as pessoas lembravam-se de Flavinus [...]. (BARKER, 1990, p. 648-649, grifo nosso)

Vê-se que a obsessão pela beleza encontra seu irmão na digressão de Gavin: o elogio da imortalidade, ponto a mais que corrobora a semelhança entre o protagonista e Dorian Gray.

Com a demora de Kenneth, Gavin decide procurá-lo e o encontra machucado, atrás de uma porta: "Um corte profundo ia da têmpora até o queixo, e outro, paralelo, mas não tão profundo, atravessava a testa e o nariz, como se tivesse sido arranhado por um garfo com dois dentes" (BARKER, 1990, p. 650). À procura de um curativo e aflito por um inesperado encontro com o provável atacante, ele entra no banheiro e percebe a presença de algo:

https://periodicos.unifap.br/index.php/letras

Macapá, v. 7, n. 4, 2을 semestre, 2017 


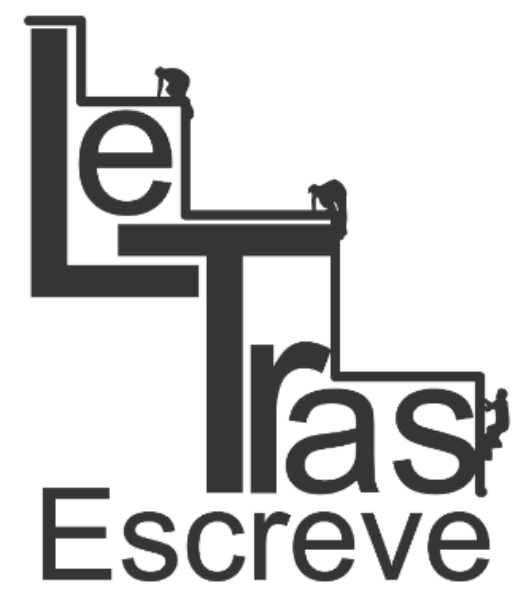

(ISSN 2238-8060)
A banheira estava cheia quase até a borda com água escura. Uma espuma marrom espiralava na superfície, e o cheiro era de alguma coisa animal, como pelo de cachorro molhado. Nada apareceu na superfície.

Gavin olhou para o fundo, tentando identificar a forma escura, e seu rosto refletiu-se na espuma. Inclinou-se mais para a frente, sem entender o que via, até reconhecer a mão com dedos toscos e perceber que estava olhando para uma forma humana encolhida como um feto, completamente imóvel na água imunda.

Passou a mão na superfície para tirar a espuma suja, seu reflexo se partiu e pôde ver a coisa na banheira. Era uma estátua, uma figura humana adormecida, mas com a cabeça torcida, olhando para os sedimentos escuros da superfície. Os olhos pintados estavam abertos, duas bolas no rosto mal esculpido; a boca era uma fenda; as orelhas, alças ridículas na cabeça calva. Estava nua, sua anatomia mal caprichada como o rosto, o trabalho de um aprendiz de escultor. Em alguns lugares, a tinta, solta talvez pelo mergulho demorado, erguia-se em tiras do torso da estátua, revelando a madeira escura.

[...] Gavin olhou para a banheira. Alguma coisa naquela estátua fascinava-o. Talvez a nudez, e aquela segunda nudez que estava acontecendo debaixo d'água, o máximo do strip-tease, a retirada da pele.

[...] Gavin não podia tirar os olhos dela, em toda sua crueza e imperfeição. Seu próprio rosto, intrigado, flutuou na superfície da água, envergonhando a mão do artista da estátua. (BARKER, 1990, p. 653655 , grifo nosso)

Mesmo na água turva, o reflexo de Gavin manifesta-se e realiza a ponte entre ele e a estátua de madeira. Segundo Umberto Eco em "Sobre os espelhos" ("Sugli specchi", 1985), o espelho (no caso, um espelho d'água) "[...] é uma prótese absolutamente neutra, e permite que se obtenha o estímulo visual onde o olho não poderia alcançar [...] Como prótese, os espelhos são canais. Um canal é cada medium material que permite a passagem de informação [...]" (ECO, 1989, p. 18, grifo do autor). É aqui que a relação entre o eu e o outro,

https://periodicos.unifap.br/index.php/letras

Macapá, v. 7, n. 4, 2ㅇ semestre, 2017 
entre Gavin e a estátua, nasce, por meio do reflexo na água, garantindo que o laço entre ambos seja firmado e, consequentemente, possibilitado o início do processo de duplicação.

Expulso por Reynolds do apartamento, o prostituto deixa o lugar, sem esquecer de rever a lápide de Flavinus e pensar: "O homem deve ter sido um herói, pensou Gavin. Só um herói seria comemorado daquele modo. Ele jamais seria lembrado assim, não teria nenhum rosto de pedra para marcar sua passagem" (BARKER, 1990, p. 656).

Mais do que intensificar sua ânsia pelo eterno, o encontro no apartamento inicia a sina de Gavin. Depois desse episódio, ele sente a presença de algo perseguindo-o nas sombras e em reflexos:

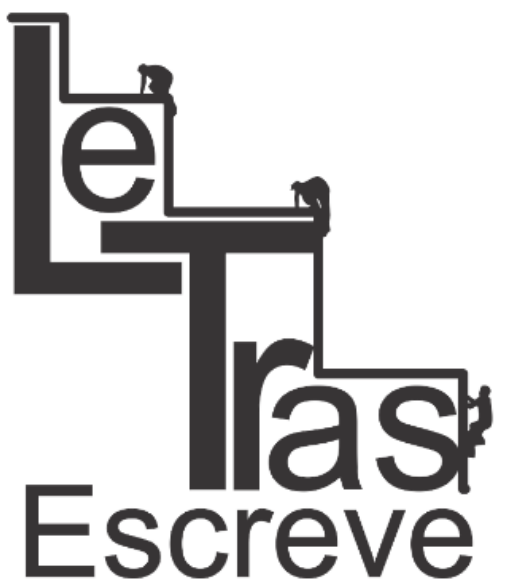

(ISSN 2238-8060)

Mas esta perseguição não era tão óbvia, era pouco mais do que a sensação de estar sendo seguido. Não possuía nenhuma prova concreta. Apenas a impressão desagradável, cada vez que olhava em volta, de que alguém escondia-se nas sombras, ou que à noite andava atrás dele, acompanhando cada movimento, cada hesitação de seus passos. Era como uma paranoia, mas acontece que ele não era paranoico. Se fosse, pensava, alguém já devia ter dito.

[...] Outra vez, numa rua movimentada, Gavin abrigou-se na entrada de uma loja vazia, para acender o cigarro, e viu o reflexo do homem, distorcido pela vitrine suja. O fósforo queimou seu dedo, Gavin abaixou os olhos, e, quando os ergueu, o homem que o vigiava fora tragado pelo mar faminto da multidão. Era uma sensação horrível, e não ficou só nisso. (BARKER, 1990, p. 657, grifo nosso)

Entre perseguição e paranoia, o estrangeiro indicia sua chegada na vida de Gavin, nas reflexões e trevas de sua rotina, à espreita do eu.

Numa noite, um cafetão, Preetorius, confronta Gavin, acusando-o de um ataque a um de "seus meninos". Apesar de negar tê-lo feito, Preetorius insiste, inclusive dizendo que a própria vítima ates-

https://periodicos.unifap.br/index.php/letras

Macapá, v. 7, n. 4, 20 semestre, 2017 
tou sua identidade: "- O garoto o reconheceu, mesmo com aquela meia na sua cabeça. A voz era a mesma, as roupas eram as mesmas. Admita, você foi reconhecido. Agora, aguente as consequências" (BARKER, 1990, p. 661). Encurralado num beco, o cafetão, conhecido por desfigurar suas vítimas, começa seu ofício:

- Permita-me remodelar seu rosto. Um pequeno crime contra a estética.

[...] - Não tem saída, escroto - disse ele, apertando a ponta da lâmina contra o queixo de Gavin, onde a saliência do osso era mais acentuada, e começou a cortar, traçando a linha do queixo, furioso demais para fazer um corte decente. Gavin soltou um urro quando o sangue escorreu para seu pescoço, mas os dedos grossos de um dos homens agarraram sua língua e seguraram-na com força. (BARKER, 1990, p. 662-663)

Nesse ataque a Gavin, o machucado sofrido por Reynolds, em que "Um corte profundo ia da têmpora até o queixo, e outro, paralelo, mas não tão profundo [...]" (BARKER, 1990, p. 650), é replicado parcialmente, prenunciando, com essa reflexão sanguinária, a iminente presença do Doppelgänger.

(ISSN 2238-8060)

A seguir, os capangas do cafetão são atacados e fogem, fazendo Preetorius largar sua presa para encarar o seu predador. Já no chão e desesperado, ele pede ajuda ao protagonista, mas sua súplica é em vão:

- Ajude-me - implorou ele, como se sua vida estivesse nas mãos de Gavin.

Ergueu a mão enorme, como que para agarrar uma gota de misericórdia no ar, mas outro braço apareceu sobre seu ombro e enfiou uma lâmina em sua boca. O negro gorgolejou uma vez, a garganta tentando acomodar a faca à sua largura, e então o atacante puxou-a para cima e para trás, segurando o pescoço de Preetorius para aguentar a força do gol-

https://periodicos.unifap.br/index.php/letras

Macapá, v. 7, n. 4, 2o semestre, 2017 
pe. $O$ rosto apavorado dividiu-se em dois, e o calor subiu do interior de Preetorius como uma nuvem, aquecendo Gavin. (BARKER, 1990, p. 664, grifo nosso)

Testemunhando o massacre sanguinolento - e dúplice, uma vez notada a divisão em duas metades da cabeça do cafetão -, o outro é revelado a Gavin:

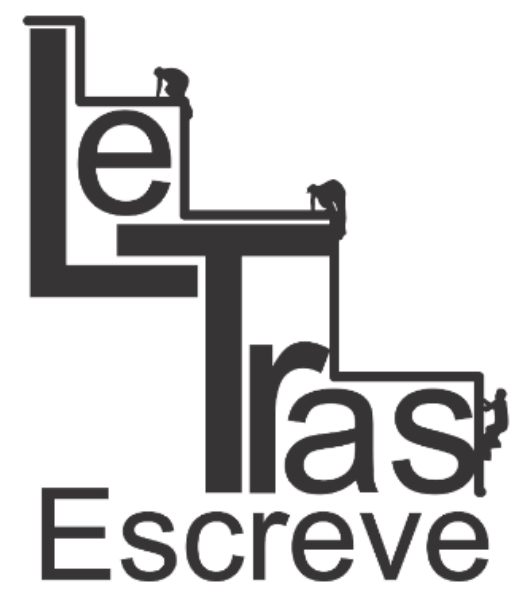

(ISSN 2238-8060)
Num instante, identificou aqueles traços toscos: os olhos assustados e sem vida, a boca como um corte no rosto, as orelhas como alças de xícara. Era a estátua de Reynolds. A coisa sorriu, mostrando dentes muito pequenos para o rosto. Dentes de leite, ainda não trocados. Mas, mesmo no escuro, Gavin notou uma melhora na aparência da estátua. A testa parecia maior, o rosto mais proporcional. Era ainda um boneco pintado, mas um boneco com aspirações. [...] A visão estendeu o braço e tocou de leve o queixo de Gavin, passando os dedos toscos nas bordas do ferimento feito por Preetorius. A luz incidiu num anel no dedo mínimo, idêntico ao de Gavin. (BARKER, 1990, p. 664-665, grifo nosso)

A estátua observada na banheira de Reynolds toma vida e começa a adquirir as características da aparência do protagonista: o duplo insurge na narrativa, mas ainda num estágio de pouca semeIhança, indicando que o processo começara a pouco. Ao falar com a vítima do beco, a estátua duplicante resvala em seu discurso no catalisador de seu processo replicante:

A estátua levou a mão ao próprio queixo, e, no mesmo lugar do ferimento de Gavin, apareceu um corte, e, logo em seguida, uma cicatriz. Não sangrou. A coisa não tinha sangue. Porém, aquela testa não imitava a sua, os olhos penetrantes não começavam a ficar como os seus, e a boca não se transformava na sua boca maravilhosa?

- E o garoto? - perguntou Gavin, juntando as pe- 
ças do quebra-cabeça.

- Oh, o garoto... - Ergueu os olhos inacabados para o céu. - Um verdadeiro tesouro! E como gritou.

- Você se banhou no sangue dele?

- Eu preciso. - Ajoelhou perto do corpo de Preetorius e pôs os dedos na cabeça partida. - Este sangue é velho, mas serve. O garoto era melhor.

Passou o sangue de Preetorius no rosto, como se fosse pintura de guerra. Gavin não disfarçou o nojo. (BARKER, 1990, p. 665, grifo nosso)

Gavin dá-se conta das semelhanças físicas - assim como os danos infligidos à sua carne, espelhados na estátua - presentes no rosto da criatura, que utiliza o sangue para pintar seu rosto em transição. Nessa percepção do familiar no estrangeiro, o Unheimliche evidencia-se, conforme descrito por Sigmund Freud em "O 'estranho'":

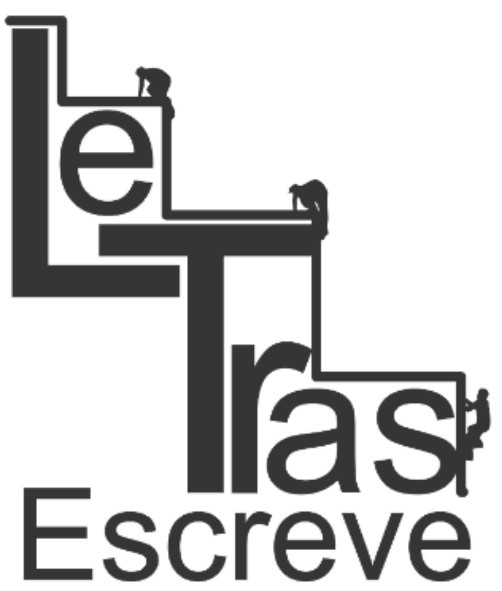

(ISSN 2238-8060) “[...] aquela categoria do assustador que remete ao que é conhecido, de velho, e há muito familiar" (1996, p. 238). O efeito dessa pintura sanguínea logo começa a transparecer no semblante do outro:

No lugar em que a coisa havia passado o sangue de Preetorius, a pele já parecia mais viva, não tanto como madeira pintada.

- Sou uma coisa sem nome - disse. - Sou um ferimento no flanco do mundo. Mas sou também o estranho perfeito, pelo qual você sempre orou quando era criança, o estranho que chegaria para buscá-lo, chamá-lo de belo, erguer seu corpo nu da rua e levá-lo, através da janela, para o céu. Não sou? Não sou? (BARKER, 1990, p. 666, grifo nosso)

Dois eixos destacam-se nas últimas falas do Doppelgänger. Primeiro, o sangue, que acelera o processo replicante e é também uma necessidade da criatura, aproximando-a, no bestiário da ficção gótica, do vampiro, criatura que se alimenta do sangue de suas vítimas, como se observa nos atos de Conde Drácula e na máxima proclamada por seu lacaio, Renfield, no romance Drácula (Dracula, 
1897), de Bram Stoker: “O sangue é vida!” (2014, p. 262). Outra questão que evidencia esse parentesco vampírico é que o conto em questão pode também ser achado na coletânea The Vampire Archives (2009), editada por Otto Penzler, constando na seção "Is That a Vampire?" - "Isso é um vampiro?" - , indício extratextual de que, apesar de não ser um vampiro tradicional, a criatura de "Restos humanos" assimila uma das marcas mais famosas desse predador: a ingestão de sangue para sobrevivência (no caso da estátua, a ingestão não é oral, mas via absorção epidérmica). Nesse momento, emerge o indício de que algo a mais alastra-se na estruturação do organismo desse duplo.

O segundo ponto é o seu nome. A entidade diz não ter um,

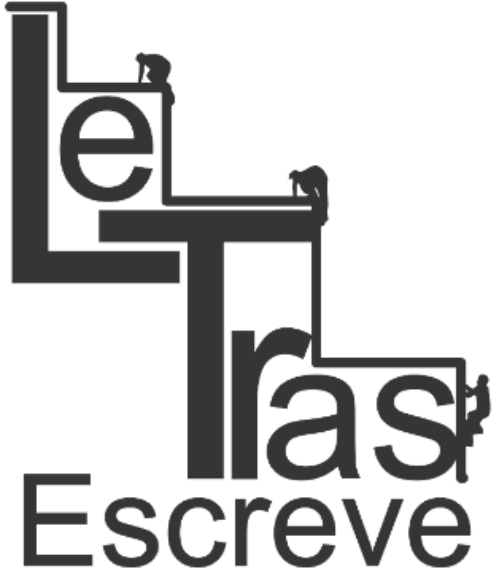

(ISSN 2238-8060) bem como declara ser o "estranho perfeito", logo afirmando no universo narrativo desse conto sua existência duplicante, o fato de ser alguém/algo que copia outros seres. Desse modo, mesmo replicando a identidade de outros, a criatura não consegue estabelecer uma própria identidade, não consegue nomear-se: permanece estranha a si mesma.

Posterior a esse encontro unheimlich, Gavin começa a planejar suas ações, mas já prevendo a reação das autoridades:

Qual seria a sua defesa? Que o culpado não era um homem, mas uma espécie de efígie que, aos poucos, estava se tornando uma réplica dele mesmo? A questão não era se iam prendê-lo ou não, mas onde o prenderiam, na cadeia ou num manicômio? (BARKER, 1990, p. 667)

O que nos leva a duvidar do próprio protagonista: seria a estátua um elemento sobrenatural ou estaria Gavin delirando? Na perspectiva de Tzvetan Todorov em Introdução à literatura fantástica (Introduction à la litterature fantastique, 1970), "O fantástico é a hesitação experimentada por um ser que só conhece as leis naturais, face a 
um acontecimento aparentemente sobrenatural" (TODOROV, 2012, p. 31). Apesar de não duvidar do acontecimento, ele duvida que outros acreditarão em sua versão dos fatos, o que insinua brevemente ao leitor a possibilidade da existência da criatura transitar entre o real e o irreal.

Retornando ao lugar onde tudo começou, Gavin reencontra Reynolds, cuja primeira reação é confundi-lo com seu outro:

- Você não me engana - disse Reynolds. - Eu sei o que você fez. Ótimo trabalho. Muito esperto.

- Quer dizer os assassinatos? Não fui eu.

Reynolds apontou a faca para Gavin.

- Quantos banhos de sangue foram necessários? perguntou com os olhos cheios de lágrimas. — Seis? Dez?

- Eu não matei ninguém.

- ... monstro.

[...] - Você está suando - disse ele. E o olhar ameaçador desapareceu.

Abaixou a mão com a faca.

- Ele jamais poderá suar - disse. - Nunca soube, nunca vai saber como. Você é o garoto... não a coisa. 0 garoto. (BARKER, 1990, p. 670-671, grifo nosso)

(ISSN 2238-8060)

A única pista que o restaurador tem é a denúncia do corpo orgânico, o suor. Isso aponta-nos à artificialidade: o corpo do duplo mimetiza a imagem da pessoa escolhida, contudo não seria, a partir da fala de Reynolds, capaz de replicar o caráter orgânico interno que um corpo humano natural transparece. Se pensarmos na sede sanguínea, o sangue supriria sua falta de líquidos corporais, ao mesmo tempo que cataliza a replicação humana. Nesse sentido, o traço artificial avizinha-o do entendimento de um andróide: ser com aparência humana, mas mecanismos internos robóticos - caso semelhante do romance Androides sonham com ovelhas elétricas? (Do Androids Dre-

https://periodicos.unifap.br/index.php/letras

Macapá, v. 7, n. 4, 20 semestre, 2017 


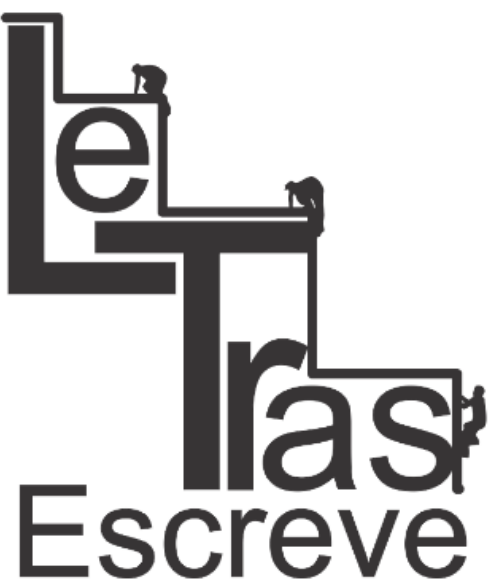

(ISSN 2238-8060)

am of Electric Sheep?, 1968), de Philip K. Dick e do filme Blade Runner, dirigido por Ridley Scott e baseado no romance de Dick, nos quais seres criados artificialmente, os replicantes, são aparentemente idênticos a seres humanos, mas passíveis de serem descobertos por meio de uma série de perguntas analisadas por uma máquina.

Discutindo com o restaurador, que arruinara sua própria casa e as peças romanas, Gavin toma conhecimento do objetivo de sua primeira visita ao apartamento: ser a fonte de sangue para a estátua. Além disso, ele descobre o estágio final do processo de replicação: "- Quando ele terminar a imitação do corpo físico, acho que irá roubar a única coisa que não pode imitar, sua alma" (BARKER, 1990, p. 672-673). Roubar a alma de sua vítima duplicada seria o objetivo final da criatura, o que suporta a ideia desse duplo portar uma casca artificial inanimada.

\section{CAMALEÕES MASCARADOS, EUS TRANSFIGURADOS}

Em busca do espectro sem nome, Gavin começa a não se importar por outro estar ocupando seu lugar na existência:

E daí, se sua vida estava sendo roubada e usada completamente em seu lugar? Ele podia dormir sabendo que ele, ou alguma coisa tão parecida com ele que não se percebia a diferença, estava acordada à noite e sendo adorada. Começou a ver a criatura, não como um monstro aterrorizador, mas como seu instrumento, quase como sua persona. A criatura era a substância; ele, a sombra. (BARKER, 1990, p. 675, grifo nosso)

Eis aqui o primeiro indício da transformação de Gavin: a metamorfose do eu no outro. Segundo Clément Rosset em $O$ real e seu duplo: ensaio sobre a ilusão (Le Réel et son double: essai sur l'illusion, 1985),

https://periodicos.unifap.br/index.php/letras

Macapá, v. 7, n. 4, 2 semestre, 2017 


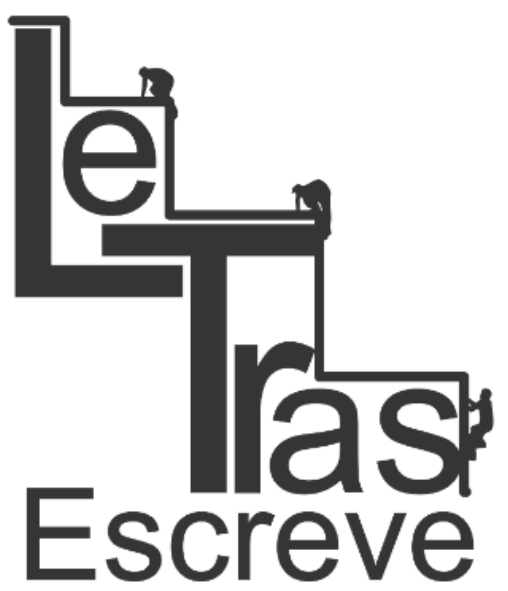

(ISSN 2238-8060)
É verdade que o duplo é sempre intuitivamente compreendido como tendo uma realidade "melhor" do que o próprio sujeito - e ele pode aparecer neste sentido como representando uma espécie de instância imortal em relação à mortalidade do sujeito. Mas o que angustia o sujeito, muito mais do que a sua morte próxima, é antes de tudo a sua nãorealidade, a sua não-existência. Morrer seria um mal menor se pudéssemos ter como certo que ao menos se viveu; ora, é desta vida mesma, por mais perecível que por outro lado possa ser, que o sujeito acaba por duvidar no desdobramento de personalidade. No par maléfico que une o eu a um outro fantasmático, o real não está do lado do eu, mas sim do lado do fantasma: não é o outro que me duplica, sou eu que sou o duplo do outro. Para ele o real, para mim a sombra. (2008, p. $88-89$, grifo do autor)

como parte do processo de replicação do Doppelgänger inominado, implicando numa relação parasitária. Gradualmente, essa metamorfose afeta o prostituto:

Sonhou com água. Estava sentado ao lado de um lago cheio de peixes, em Fort Lauderdale. E o ruído molhado dos saltos e mergulhos dos peixes continuava, como que derramando-se do sonho. Ou seria o contrário? Sim, ouvira água correndo enquanto dormia, e o sonho criou um quadro para acompanhar o que ouvia. Agora, acordado, o som continuava.

[...] Atravessou o quarto para apanhar o roupão dependurado atrás da porta e viu-se no espelho, uma moldura gelada para um filme de terror, um arremedo de homem, encolhido pelo frio, iluminado pela luz fraca e indecisa. Tão insubstancial que a imagem parecia bruxulear no espelho. (BARKER, 1990, p. 676-677, grifo nosso)

Nesse casulo de sonhos aquáticos, a transformação de Gavin continua, culminando em sua transmutação de ser físico para "insubstancial", em sombra, em outras palavras, num espectro cujo re- 
flexo começa a falhar, a "bruxulear" diante da superfície catóptrica.

No banheiro, ele tem seu segundo encontro com a criatura numa banheira. Enquanto no primeiro ela era uma estátua de madeira, agora ela manifesta-se como uma "cópia perfeita":

Olhou para a água. Lá estava a coisa, deitada, como antes, dormindo toda vestida como se não tivesse tido tempo de tirar a roupa antes de se esconder. A cabeça, antes calva, estava coberta de fartos cabelos, e os traços do rosto, completos. Não havia nem sinal do rosto pintado. Aquela coisa tinha uma beleza plástica que era Gavin, exatamente Gavin. As mãos perfeitas estavam cruzadas sobre o peito. (BARKER, 1990, p. 677, grifo nosso)

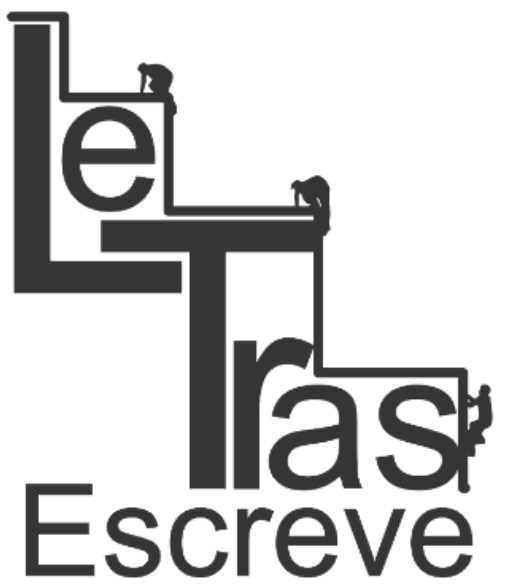

(ISSN 2238-8060)

Não mais uma estátua com vida - como se observa na temática dos contos "A estátua de mármore" ("Das Marmorbild", 1819), de Joseph Eichendorff e "A Vênus de Ille" ("La Vénus d'Ille", 1837), de Prosper Mérrimée -, o outro tornara-se eu; não mais a cópia eivada de madeira, mas o apogeu da identidade perfeita.

Cansado, ele volta ao seu sono e novamente a água volta: “No meio da noite, acordou com sede. Estava sonhando com água e ouvia o som na banheira, como antes. A criatura estava saindo do banho, segurando a maçaneta da porta, abrindo" (BARKER, 1990, p. 677). Segundo Gaston Bachelard em A água e os sonhos: ensaio sobre a imaginação da matéria (L'Eau et les rêves: essai sur l'imagination de la matière, 1941), "[...] a água, por seus reflexos, duplica o mundo, duplica as coisas. Duplica também o sonhador, não simplesmente como uma vã imagem, mas envolvendo-o numa nova experiência onírica" (2002, p. 51). Os próprios sonhos de Gavin são contaminados pela transformação, indiciando, em suas enchentes, o espelho d'água que reflete o eu, a metamorfose do eu "original" em reflexo sombrio, 
em imagem espectral.

Ferida, a criatura clama por ajuda:

- Quer me ajudar? - pediu ele. Não havia o menor sinal de ameaça na voz. Era como um irmão pedindo a ajuda de outro.

[...] - Preetorius tem amigos - disse o outro, tocando as bordas do ferimento. Gavin lembrou-se de um quadro na parede da casa de sua mãe. Cristo em toda a sua glória - o Sagrado Coração flutuando dentro do Salvador - , e os dedos, apontando para a agonia sofrida, diziam: "Isto é para você."

- Por que você não está morto?

- Porque ainda não estou vivo - disse a coisa.

Ainda não, lembre-se disso, pensou Gavin. Insinuação de mortalidade. (BARKER, 1990, p. 678, grifo nosso)

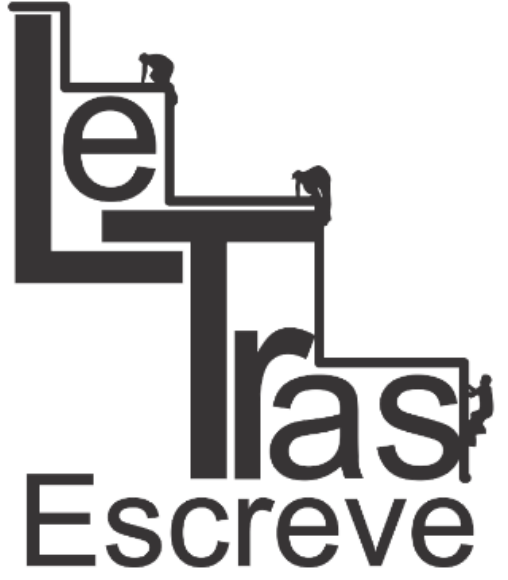

(ISSN 2238-8060) aproximação: o duplo é comparado a Cristo. Não mais um agouro da morte, o tom que cobre a criatura começa a tomar um caminho luminoso, das trevas à luz, da morte à vida, como ela mesma fala a Gavin, "Porque ainda não estou vivo", denunciando seu trânsito entre esses dois pólos. Consequentemente, a afirmação leva-nos a supor que tal Doppelgänger seria um morto-vivo, um ser que venceu a morte e continuou a vagar na vida:

A coisa olhava para ele com olhos perfeitos, idênticos aos seus.

[...] Eu preciso de sangue e isso faz de mim um monstro. Na minha juventude, um mês atrás, eu me banhei em sangue. A madeira adquiriu a aparência de carne. Mas não preciso mais, o processo está quase terminado. Só preciso agora...

[...] - Já vivi várias vezes, você sabe. Em certas ocasiões, roubei vidas e consegui o que queria. Vivi por um tempo normal, depois desfiz-me do rosto que estava usando e encontrei outro. Às vezes, como na última, fui desafiado e perdi... (BARKER, 1990, p. 679, grifo nosso) 
Ao afirmar ter vivido e morrido diversas vezes, a criatura atesta ser uma espécie de morto-vivo, que fortemente evoca um determinado tipo: o lich,

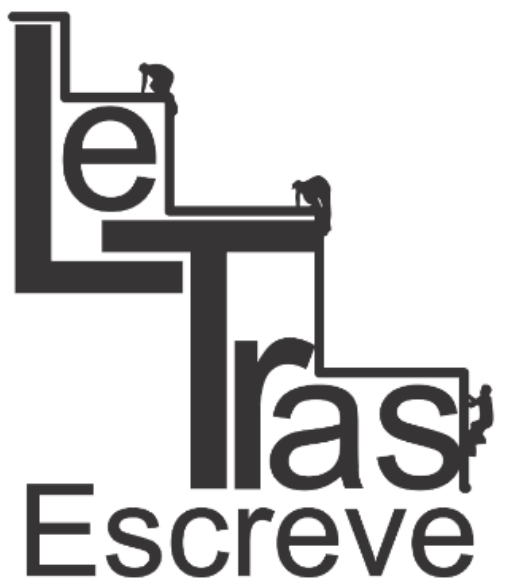

(ISSN 2238-8060)

[...] uma criatura maligna, tipo específico de mortovivo [...]. Trata-se, na verdade, de um ser humano que, em vida, buscou incessante e incansavelmente conhecimentos ocultos e proibidos, tendo se tornado, por meio dessa busca, um feiticeiro muito poderoso, um rei ambicioso ou ambas as coisas. Não contente com sua condição humana, em tudo limitada e limitadora dos seus ideais de poder incondicional e infindo, esse humano utilizou os conhecimentos herméticos que adquiriu para se tornar imortal e eterno por meio de um ritual de necromancia que, se efetuado com sucesso, resulta na transformação do que era mortal e perecível em imortal e imperecível. (ROSSI, 2015, p. 134)

Apesar da necromancia parecer ausentar-se aqui - a não ser que consideremos o processo de replicação como uma habilidade desenvolvida pelo domínio das artes das trevas -, a leitura do Doppelgänger como um lich é possibilitada pelas muitas vidas, que ele mesmo clama, usufruídas e por ainda estar vivo. A imortalidade do sósia ecoa a ânsia de Gavin pelo eterno; além do "roubo de identidade", a "cópia" é o sonho vivo do gigolô, concentrando a perfeição do seu corpo e o desejo inalcançável de ser imortal. Conforme citado anteriormente, "[...] não é o outro que me duplica, sou eu que sou o duplo do outro. Para ele o real, para mim a sombra" (ROSSET, 2008, p. 89 , grifo do autor).

Continuando o diálogo, a pergunta de Gavin corrobora nossa visão discutida acerca da artificialidade:

- Você é uma espécie de máquina?

- Não.

- O que é, então?

https://periodicos.unifap.br/index.php/letras

Macapá, v. 7, n. 4, 2 semestre, 2017 
- Sou o que sou. Não conheço nenhum outro igual a mim, mas por que devo ser o único? Talvez existam outros, muitos outros, só que eu não os encontrei ainda. Assim, eu vivo e morro e vivo outra vez, e não aprendo nada - falou com amargura a meu respeito. Você compreende? Você sabe o que é, porque vê outros iguais. Se estivesse sozinho na terra, como ia saber o que era? Só o que o espelho pode mostrar. $O$ resto seria mito e conjectura. (BARKER, 1990, p. 679, grifo nosso)

Negando ser uma máquina - sem justificar sua negativa, o que não descarta a possibilidade de ser um portador de mecanismos robóticos ou algum tipo de tecnologia extremamente avançada - , a estátua não consegue descrever o que é. Suas vidas e mortes somente perpetuam sua infindável busca por auto-descoberta e pelos eus que replica. A única verdade que possui é o seu reflexo, sua imagem replicada, e, como descreve, o restante é "mito e conjectura". Em um mundo de estranhos, o próprio eu do sósia continua desconhecido para si, permanecendo o único de uma espécie, cujo impulso é tornar-se outro: a busca pela identidade por um camaleão de vários rostos, vidas e mortes.

Sentado e observando seu "irmão", o protagonista volta a so(ISSN 2238-8060) nhar e nessa descrição, a oscilação entre o real e o onírico acontece, juntamente com a presença contínua da água:

A água jorrou. Ele sonhou com água. A criatura despiu-se. Ele sonhou com sexo. Parou ao lado dele, com o peito intato, e Gavin sentiu-se seguro com sua presença. Sonhou, por um instante apenas, que estava sendo erguido da rua para a janela do céu. [...] Finalmente, a criatura inclinou-se ao lado da cadeira e o beijou nos lábios, um beijo de irmão, e saiu. Gavin ouviu quando ela bateu a porta.

Depois disso, houve dias, ele não sabia ao certo quantos, em que ficou no quarto, sem fazer outra coisa a não ser tomar água. Era uma sede insaciável.

https://periodicos.unifap.br/index.php/letras

Macapá, v. 7, n. 4, 2o semestre, 2017 
Tomar água e dormir, tomar água e dormir, luas gêmeas.

Nos primeiros dias, a cama estava molhada no lugar em que a criatura havia dormido, e Gavin, muito cansado para trocar os lençóis. Na verdade, sentia prazer naquela umidade que seu corpo absorvera depressa demais. Então, Gavin tomou banho na água usada pela criatura e voltou para a cama encharcado, arrepiado de frio, envolto no cheiro de bolor. Mais tarde, indiferente demais para se mover, esvaziou a bexiga na cama, e aquela água, depois de algum tempo, ficou fria, até secar com o calor de seu corpo. (BARKER, 1990, p. 680-681)

Numa dieta de água e sonhos, Gavin chega em seu último estágio de transformação: assim como a criatura utiliza sangue para se alimentar e catalisar o processo de duplicação, o prostituto somente

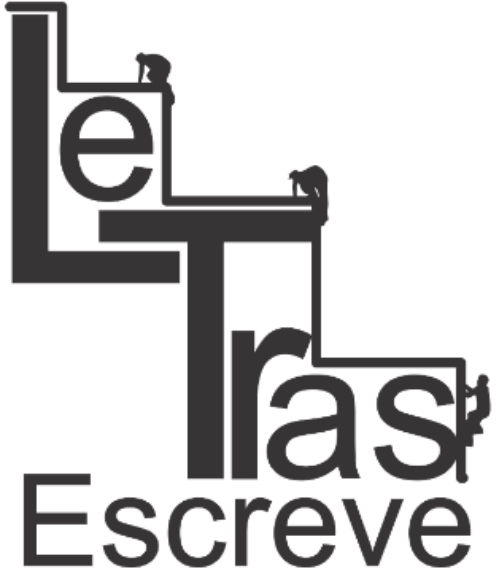

(ISSN 2238-8060) ingere água e se banha no líquido turvo, fruto do banho de seu outro. Utilizando os restos daquele que agora porta o corpo e o rosto perfeitos de Gavin, o protagonista espelha a cena no apartamento de Reynolds, em que, no interior de uma banheira, a criatura jazia na água limosa. Nas palavras de Bachelard:

Existem sonhadores de água turva. Eles se maraviIham com a água negra da fossa, com a água trabaIhada pelas bolhas, com a água que mostra veias em sua substância, que provoca, como por si mesma, um redemoinho de lodo. Parece então que é a água que sonha e se cobre de uma vegetação de pesadelo. $(2002$, p. 146$)$

Fora do apartamento, Gavin visita o túmulo de seu pai e um diálogo unheimlich "acontece" entre os dois:

Olhando para a pedra, as palavras saíram quase sem que ele percebesse, como se o pai estivesse sentado na beirada do túmulo, balançando as pernas, penteando o cabelo com os dedos, fingindo, como sem- 


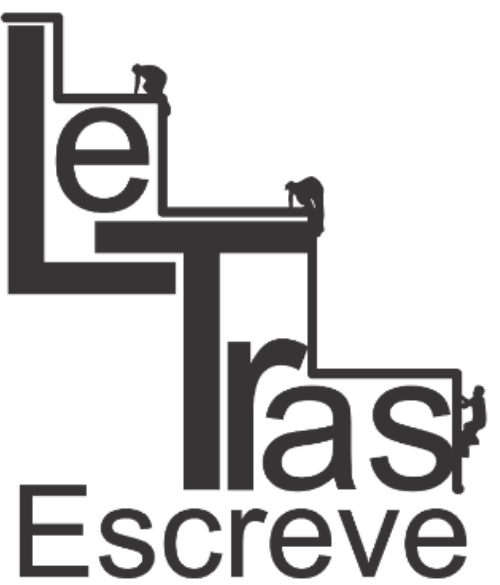

(ISSN 2238-8060) pre fazia, que realmente se importava com alguma coisa.

- Então, o que você acha?

O pai não parecia impressionado.

- Não sou grande coisa, sou? - perguntou Gavin.

Concordo com você, meu filho.

- Bem, sempre tive cuidado, como me ensinou. Nenhum filho da mãe anda por aí à minha procura.

\section{Estou muito satisfeito com isso.}

- Não encontrariam muita coisa, certo?

[...] Então, ele desapareceu.

- Seu velho monte de merda. (BARKER, 1990, p. 682-683, grifo nosso)

Imaginação ou delírio, é mister notar que quem assume a fala do pai é o narrador, ganhando outra personalidade, e, por extensão, entrando nos jogos dúplices que tematizam sua narrativa e duplicando seu próprio ato narrativo. Um narrador duplo contando uma história sobre duplos, um pai-narrador que incute em seu discurso o mesmo processo que o sósia de seu filho empregou: mimetizar o rosto de um outro.

Terminado seu pseudodiálogo, os dois Gavins encontram-se diante dos restos mortais do pai:

Lá estava ele - ele próprio - de pé, completamente imóvel a poucos metros, com a roupa de Gavin, que havia apanhado há uma semana no apartamento. Estava amarrotada e suja. Mas a carne! Oh, era mais radiante do que a sua jamais fora. Quase briIhava na luz incerta do dia chuvoso, e as lágrimas nas faces do seu fantasma ${ }^{2}$ davam maior encanto aos traços.

- Qual é o problema? - perguntou Gavin.

- Sempre que venho aqui, sinto vontade de chorar.

- Caminhou para Gavin passando por cima dos tú-

\footnotetext{
${ }^{2}$ Apesar do vocábulo "fantasma" incitar novos jogos de significação à criatura, o termo não traduz fielmente a palavra no original: "[...] and the tears on the doppelganger's cheeks only made the features more exquisite" (BARKER, 2009, p. 755, grifo nosso). Logo, possíveis caminhos, considerando a fidelidade ao texto em inglês, seriam usar o termo no original ou traduzir como "duplo".
}

https://periodicos.unifap.br/index.php/letras

Macapá, v. 7, n. 4, 2 semestre, 2017 
mulos, os passos estalando no cascalho, deslizando na grama. Tão real.

[...] aquela coisa orgulhava-se das próprias lágrimas, glorificava-se nelas. Eram o seu triunfo.

E, mesmo então, percebendo que a criatura o havia dominado completamente, Gavin não conseguia sentir nada que parecesse sofrimento.

- Fique com tudo - disse ele. - Fique com o ranho. Faça bom proveito.

A criatura mal ouvia.

- Por que tudo é tão doloroso? - perguntou ela, depois de uma pausa. - Por que é a dor da perda que me faz humano? (BARKER, 1990, p. 683-684, grifo nosso)

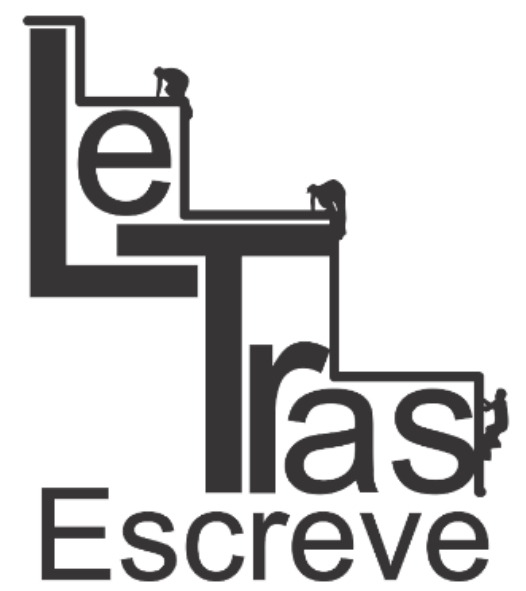

(ISSN 2238-8060)

A criatura completa, assim, o processo de replicação: o novo Gavin consegue reparar o corpo perfeito do velho Gavin, adicionar um brilho inédito ao rosto do prostituto e superar os mistérios orgânicos - as lágrimas - do corpo humano. Ele consegue chorar, e mais ainda, sentir a perda do pai - o que, segundo aquele que um dia fora inumano, é o que o faz pertencer à raça humana. As emoções do prostituto também passam pelo crivo duplicante da cópia: enquanto o Gavin de outrora era indiferente ao pai e aos seus clientes, o novo Gavin aperfeiçoa as velhas emoções e, por conseguinte, as altera. Nesse aprimoramento, a cópia, tornando-se o eu e o hipercorrigindo, altera-se. Logo, a antiga estátua demuda-se em um outro do outro do eu.

Com tudo arrancado do protagonista e este transformado na sombra do que um dia fora, ele abandona tudo e se entrega ao Destino:

Gavin saiu da calçada para o meio do tráfego, sem olhar para os lados, ignorando as freadas, os palavrões, e começou a andar entre os carros, como se estivesse num campo aberto.

O para-lama de um carro raspou sua perna, outro quase colidiu com ele. Aquela ansiedade para che-

https://periodicos.unifap.br/index.php/letras

Macapá, v. 7, n. 4, 20 semestre, 2017 
gar ao lugar do qual logo estariam ansiosos para partir era ridícula. Deixe que praguejem, que o odeiem, que vejam seu rosto sem formas e sigam para casa, assombrados. Se as circunstâncias fossem favoráveis, talvez um deles entrasse em pânico e, em vez de desviar, o atropelasse. Qualquer coisa estava bem. Daquele momento em diante, ele pertencia ao acaso, do qual seria o Porta-Estandarte para sempre. (BARKER, 1990, p. 684-685, grifo nosso)

Com o rosto transfigurado, "sem formas", Gavin aceita sua transformação e se torna o porta-estandarte do acaso, abandonando sua identidade, seu apego à vida e sua obsessão pelo perpétuo. Gavin metamorfoseia-se, enfim, num espectro errante entregue à própria sorte.

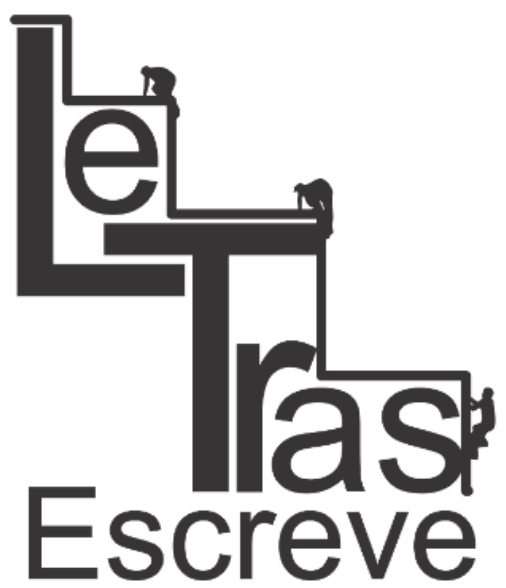

(ISSN 2238-8060)

\section{CONSIDERAÇÕES FINAIS}

Linda Badley, em "Clive Barker Writing (from) the Body", capítulo de seu livro Writing Horror and the Body: The Fiction of Stephen King, Clive Barker, and Anne Rice (1996), relata que

Os Livros de sangue foram um "recital" perverso do corpo como um texto - uma dissecação, uma "sonda exploratória", como diz William Gibson. Cada "leitura" presume a metáfora, na qual o corpo literal corresponde ao verdadeiro e transgride a lei da ordem simbólica. Nessa metáfora, "abrir" o corpo significa ler os nossos mais profundos (pré-edípicos) eus. As imagens biológicas são metáforas para ideias. A carne torna-se palavra, o texto torna-se ferida, a parte torna-se o todo, e o clichê é encorpado, dolorosamente com frequência. Os títulos em si são multivalentes com jogo de palavras: [...] clichês ironicamente distorcidos ("Restos humanos"). (1996, p. 75$)^{3}$

\footnotetext{
${ }^{3}$ No original: "The Books of Blood were a perverse 'recitation' of the body as a text $-a$

https://periodicos.unifap.br/index.php/letras

Macapá, v. 7, n. 4, 2 semestre, 2017
} 
O banho de sangue para a catalização do processo replicante - e consequente humanização -; a imortalidade do corpo monstruoso; a hiperperfeição da corporeidade da duplicata; a degradação da perfeição corporal humana; esses exemplos evidenciam como a perversão corpórea, apontada por Badley, pervade o texto de "Restos humanos".

Junto à essa questão, o tema do Doppelgänger ganha aqui novas máscaras, já que em vários momentos outras entidades ficcionais são ecoadas no tecido corporal dessa criatura: o vampiro, na ingestão do sangue; o lich, no quesito da imortalidade; a estátua que adquire vida; o androide que facilmente passa-se por ser humano. Dimanante disso, não só o corpo do humano é distorcido - a transformação degradante que Gavin sofre, culminando em uma transfiguração espectral - , assim como o do monstro, que, a cada camada, a cada máscara, revela um aspecto que transgride a ordem do corpo e da Razão.

Vê-se, também, que a imortalidade desempenha um papel na relação eu-outro, tanto antes da vinda do estrangeiro, quanto na sua chegada. Como disserta Otto Rank, em seu livro O duplo: um estudo psicanalítico (Der Doppelgänger: eine psychonalytische Studie, 1925),

(ISSN 2238-8060)

[...] o narcisismo primitivo, sentindo-se ameaçado pela inevitável anulação do Eu, criou como primeira representação da alma uma imagem o mais idêntica possível ao Eu corpóreo, portanto, um verdadeiro duplo. Assim, a ideia da morte é desmentida através de uma duplicação do Eu que se corporifica na sombra ou no reflexo.

dissection, an 'exploratory probe,' as William Gibson says. Each 'reading' presumes the metaphor in which the literal body stands for the real and transgresses the law of the symbolic order. In this metaphor, 'opening' the body means reading our deepest (preOedipal) selves. Biological images are metaphors for ideas. Flesh becomes word, text becomes wound, part becomes whole, and cliché is embodied, often painfully. The titles alone are multivalenced with word play: [...] ironically twisted clichés ('Human Remains')". O trecho citado do livro de Linda Badley foi traduzido pelo autor do presente artigo.

https://periodicos.unifap.br/index.php/letras

Macapá, v. 7, n. 4, 2ㅇ semestre, 2017 
[...] o duplo personificado no amor-próprio narcisista torna-se rival no amor sexual; ou, ainda, tendo sido criado originalmente como uma defesa contra o desejo da temida destruição eterna, reaparece na superstição como um mensageiro da morte. (2013, p. $138 ; 142)$

Observando o caminho do Doppelgänger na narrativa, vê-se tanto o rastro de morte - os assassinatos; os banhos de sangue; o espectro do acaso que Gavin torna-se - quanto a perpetuação da vida - a imortalidade da criatura e sua comparação a Cristo - indicadas por Rank quando da vinda do outro na estrada do eu. Portanto, a inclinação do segundo Gavin às pulsões de vida e morte segue ambígua assim como sua identidade, já que na tentativa de se tornar um

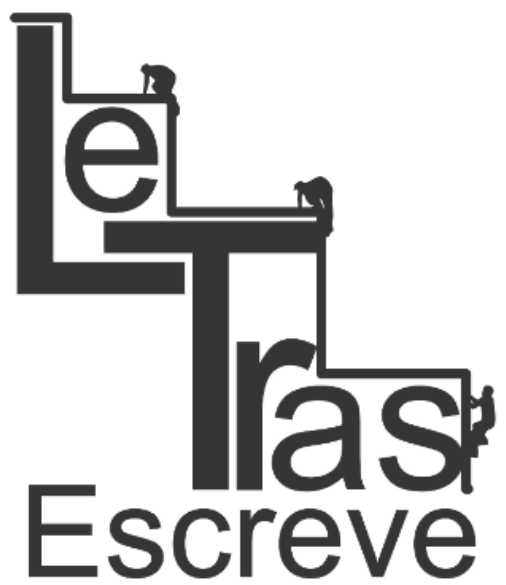

(ISSN 2238-8060) eu, o duplo transforma-se em alguém além do eu, volta novamente a ser outro.

Nossa análise desse texto, assim, não foi tentar classificar o ser que duplica a personagem principal, o que dissiparia a geração e subversão de significação promovidas pelo conto em questão, mas sim visualizar como algumas máscaras travestidas por esse ser inovam a abordagem do motivo em questão, incutindo no ente duplicante idiossincrasias de outras entidades ficcionais e, com isso, perpetuando o enigma identitário em torno da estátua, enigma este insolúvel para ela própria, que não conseguiu resolvê-lo após as vidas e mortes de sua miríade de rostos replicados.

\section{Referências}

BACHELARD, G. A água e os sonhos: ensaio sobre a imaginação da matéria. São Paulo: Martins Fontes, 2002.

BADLEY, L. Clive Barker Writing (from) the Body. In: Writing

Horror and the Body: The Fiction of Stephen King, Clive Barker, and 
Anne Rice. Westport, CT: Greenwood Press, 1996, p. 73-104.

BARKER, C. Human Remains. In: PENZLER, Otto (Ed.). The Vampire Archives. New York; London: Random House, 2009, 733-756. Restos humanos. In: . Livros de sangue. Rio de Janeiro: Civilização Brasileira, 1990, p. 635-685. PDF.

ECO, U. Sobre os espelhos. In: Sobre os espelhos e outros ensaios. Rio de Janeiro: Nova Fronteira, 1989, p. 11-37.

FREUD, S. O 'estranho'. In: . Edição standard brasileira das obras psicológicas completas de Sigmund Freud. Rio de Janeiro: Imago, 1996, v. XVII, p. 233-273.

RANK, O. O duplo: um estudo psicanalítico. Porto Alegre: Dublinense, 2013.

ROSSET, C. O real e seu duplo: ensaio sobre a ilusão. 2. ed. rev. Rio de Janeiro: José Olympio, 2008. (Sabor Literário).

ROSSI, A. D. Ressurectum de Tenebris: o Lich na Ficção. Abusões, Rio de Janeiro, v. 1, n. 1, p. 122-154, 2015. Disponível em:

$<$ http://www.e-

publicacoes.uerj.br/index.php/abusoes/article/view/20429/15241>. Acesso em: 10 jun. 2017.

(ISSN 2238-8060)

STOKER, B. Drácula. São Paulo: Penguin Classics Companhia das Letras, 2014.

TODOROV, T. Introdução à literatura fantástica. 4. ed. São Paulo: Perspectiva, 2012. (Debates, 98).

WILDE, O. O retrato de Dorian Gray. São Paulo: Penguin Classics Companhia das Letras, 2012.

Recebido em 02/08/2017

Aceito em 04/11/2017 